Lidia Dakowicz Andrzej Dakowicz Uniwersytet w Biatymstoku

\title{
Marital Satisfaction: A Psychological and Pedagogical Analysis of the Social Competence of Spouses
}

The aim of the study is to determine whether a spouse's social competence affects the level of his or her marital satisfaction. Using M. M. Braun-Gałkowska's Scale of Marital Success as well as A. Matczak's Social Competence Questionnaire, this study examined 75 marriages, from which 30 couples with higher and lower level of relationship satisfaction were identified. Spouses with a higher level of satisfaction with their relationship are characterized by greater competence in terms of the effectiveness of intimate behaviors than those with a lower level of satisfaction. In addition, husbands who were more competent in situations that required assertiveness were more satisfied in their marital relationship. Spouses with greater social skills are able to build a closer marital relationship that positively affects the atmosphere of family life.

Key words: marital success, social competence, intimate situations, social exposure, assertiveness, family atmosphere. 


\section{Introduction}

The quality of a marital relationship, which is the result of many variables, ${ }^{1}$ also affects the psychological state of the spouses. ${ }^{2}$ Because marital relationships are the basis of the entire family ${ }^{3}$ and greatly affect the atmosphere within the family, ${ }^{4}$ it is worthwhile to determine the factors that significantly influence the sense of satisfaction that the spouses get from their relationship. One essential factor that affects the quality of the interpersonal relationship between a husband and wife is the spouses' social competence, which can result from certain influences depending on which theoretical approach one takes. For example, Michael Argyle points out that the ability to verbally and nonverbally communicate rewards, coming to an agreement quid pro $q u o$, and improving communication and problem solving influences marital satisfaction. ${ }^{5}$ When writing about eliciting sympathy, love, and interpersonal sensitivity, Elliot Aronson emphasizes, among other things, the influence of praise and favors, personal qualities, and communication. ${ }^{6}$ In literature on this subject, it is also possible to find specific approaches to social competence with regard to marital relations. These studies focus on, for example, self-giving, ${ }^{7}$ constancy in an ever-changing world, communal development, ${ }^{8}$ and marital dialog. ${ }^{9}$

$1 \quad$ B. Jankowiak and K. Waszyńska, "Współczesne formy życia partnerskiego. Analiza jakości i trwałości relacji,” Nowiny Lekarskie 80, no. 5 (2011): 360-363.

M.Król-Fijewska, "Historie małżeńskie,"Sztuka relacji międzyludzkich.Miłość, matżeństwo, rodzina, ed. J. Augustyn (Cracow: Wydawnitcwo WAM, 2014): 313-320.

M. Braun-Gałkowska, "Psychoprofilaktyka życia rodzinnego," Psychologia w stużbie rodziny, eds. I. Janicka, and T. Rostowska (Lodz: Fundacja Fides et Ratio, 2003): 11.

W. Świętochowski, "Rodzina w ujęciu systemowym,” Psychologia rodziny, eds. I. Janicka, H. Liberska (Warsaw: 2014): 31-32.

M. Argyle, The Psychology of Interpersonal Behavior. E-Book: Kindle (United Kingdom: Penguin, 1994), 163.

E. Aronson, The Social Animal (New York: Worth Publishers, 2008), 357-403.

M. Braun-Gałkowska, Psychologia domowa (Lublin: Wydawnictwo Katolicki Uniwersytet Lubelski, 2008), 126.

A.K. Ładyżyński, "Razem w niestabilnych czasach," Sztuka relacji międzyludzkich.Mitość, matżeństwo, rodzina, ed.J.Augustyn(Cracow: Wydawnictwo WAM 2014): 331-337.

$9 \quad$ A. Dakowicz, Powodzenie matżeństwa. Uwarunkowania psychologiczne w perspektywie transgresyjnego modelu Józefa Kozieleckiego (Bialystok: Wydawnictwo Uniwersyteckie Trans Humana, 2014), 91. 
In this study, social competence is understood as attainable by the spouses in the process of social formation and comprehensive skills that condition how effectively a person manages situations that require intimacy, social exposure, and assertiveness. ${ }^{10}$

\section{Social Competence Determines the Effectiveness of Functioning in a Family}

Spouses affect each other because they live together, have daily contact, and are also emotionally bonded with each other and particular members of the family. ${ }^{11}$ They also affect each other because their relationship is constantly changing ${ }^{12}$ from the moment that they plan to become parents, ${ }^{13}$ to the time when they actually fulfill their roles as parents, ${ }^{14}$ not to mention the continually new challenges that arise throughout the course of marriage. The effectiveness of the spouses' ability to function in a family environment requires that they be able to cope in intimate situations (e.g., sharing one's personal problems and listening to the personal problems of one's spouse). ${ }^{15}$ This effectiveness also depends on how the spouses present themselves to each other, which is motivated by their need to obtain material and social benefits, and by self-assurance, meaning having a sense of one's own value and forming the identity that one desires to have. ${ }^{16}$ This effectiveness is also tied to the spouses' ability to strive for what they want without

10 A. Matczak, Kwestionariusz Kompetencji Społecznych. Podręcznik (Warsaw: Pracownia Testow Psychologicznych 2001), 7-11.

11 B. Harwas-Napierała, "Specyfika komunikacji interpersonalnej w rodzinie ujmowanej jako system," Psychologia rodziny, eds. I. Janicka and H. Liberska (Warsaw: 2014): 48.

12 M. Walczak, "Dylematy życia małżeńskiego. Rzecz o dynamice i kryzysach w relacjach małżeńskich," Psychologia w stużbie rodziny, eds. Janicka and T. Rostowska (Lodz: Fundacja Fides et Ratio 2003): 102-108.

$13 \quad$ K.Kuryś-Szyncel, "Od małżeństwa do rodzicielstwa. Analiza zmian rozwojowych w systemie rodzinnym," Rodzina w ujęciu systemowym. Teoria $i$ badania, ed. A. Margasiński (Warsaw: Pracownia Testów Psychologicznych 2015): 100-118.

A. Dakowicz, "Postawy rodzicielskie małżonków zadowolonych i niezadowolonych ze swojego związku,"W świecie dziecka. Wybrane zagadnieniazpsychologii wychowawczej i rodziny, eds. B. Lachowska and M. Grygielski (Lublin: 1999): 73-87.

A. Matczak, Kwestionariusz Kompetencji Społecznych, 11.

M. R. Leary, R.M. Kowalski, "Impression Management: A Literature Review and Two-Component Model," Psychological Bulletin 107, no. 1 (American Psychological Association, 1990): 34-47. 
hurting others. ${ }^{17}$ With regard to the reality of family life, the effective ability to function in a family environment is also connected with the spouses' ability to initiate, engage in, and conclude conversations, as well as an ability to say "no," to express positive and negative feelings, and to arouse positive emotions in other family members. ${ }^{18}$

When taking into consideration the nature of social competence, which greatly influences close interpersonal relationships, the question arises: Do spouses with either a higher or lower level of relationship satisfaction differ from each other with regard to their social competence? If they differ, which forms of social competence do those with higher satisfaction possess? To answer these questions, this study will compare the social competence scores of a group of spouses who differ from each other only in the level of their marital satisfaction.

\section{Research Method and Study Participants' Characteristics}

To conduct this study, spouses were separated into two groups: those who experience high marital satisfaction and those who experience low marital satisfaction. Once these two groups were established, the social competence levels of those in the high satisfaction were compared to the social competence levels of those in the low satisfaction group.

To determine the spouses' level of satisfaction, this study used M. M. Braun-Gałkowska's Scale of Marital Success, ${ }^{19}$ which is made up of 46 assertions that address essential elements of a successful marriage. In the first half of the survey, the participants responded to statements that characterize their marriages. In the second half of the survey, the participants noted which characteristics are most important to them for a successful and happy marriage. By comparing the results of both sections of the survey scale, we then determined a numerical index of marital satisfaction on a scale of 0 (complete marital dissatisfaction) to 100 (complete marital satisfaction). Many researchers use

17 R. Alberti, M. Emmons, Asertywność. Sięgaj po to, czego chcesz, nie raniąc innych (Gdansk: Gdanskie Wydawnictwo Psychologiczne, 2007).

$18 \quad$ R. S. Lazarus, "On the Primacy of Cognition," American Psychologist 39, no. 2 (Washington, DC: American Psychological Association, 1984): 124-129. 
the Scale of Marital Success in their studies ${ }^{20}$ due to its high accuracy and reliability. ${ }^{21}$

In order to determine the spouses' levels of social competence, we used A. Matczak's Social Competence Questionnaire, ${ }^{22}$ which made it possible to determine the overall results as well as the effectiveness of social and assertive behavior. The psychometric indicators of this questionnaire confirm that it is a reliable tool. ${ }^{23}$

Seventy-five married couples took part in this study. In order to participate, these couples had to meet the following inclusion criteria: be in their first formal marital relationship; married at least 5 years; received either high school or college education; professionally active; and raising at least two children. ${ }^{24}$ Based on the results of the Marriage Success Scale, 30 couple exhibiting higher and lower levels of satisfaction were identified. ${ }^{25}$ In the higher marital satisfaction group, the average marital satisfaction score for wives was 82.8 (lowest 67, highest 100) and for husbands was 86.4 (lowest 65, highest 100). Within this group, the spouses' average marriage length was 16.2 years. The average age of the wives was 40.4 years, and of the husbands 41.1 years. Wives with higher levels of satisfaction with marriage were more likely to have received a higher education $(66.7 \%)$ than a secondary education $(33.3 \%)$. In the case of the husbands tested, the opposite trend was observed: husbands who were more satisfied with their marriage were more likely to have a secondary education (53.3\%) than a higher education $(46.7 \%)$.

In the second group, which was made up of spouses who were less satisfied with their marital relationships, the wives' average marital satisfaction score was 45.1 (lowest 6 , highest 90 ) while the husbands'

$20 \quad$ H. Elżanowska, "Skala Powodzenia Małżeństwa w badaniach prowadzonych pod kierunkiem Profesor Marii Braun-Gałkowskiej," in Dalej w tę sama strone.. Ksiega Jubileuszowa dedykowana Profesor Marii Braun-Gatkowskiej, eds. I. Ulfik-Jaworska and A. Gała (Lublin: Wydawnictwo Katolicki Uniwersytet Lubelski, 2012), 61-87.

M. Braun-Gałkowska, Psychologiczna analiza systemów rodzinnych osób zadowolonych iniezadowolonych z matżeństwa (Lublin: Towarzystwo Naukowe KUL, 1992), 46.

A. Matczak, Kwestionariusz Kompetencji Społecznych.

Ibid, 17.

This research was conducted by those who participated in the master's seminar under the direction of Dr. Andrzej Dakowicz of the Department of Social Psychology and Human Development at the University of Bialystok's Faculty of Pedagogy and Psychology. 
average score was 49.0 (lowest 8 , highest 95). In this group, couples had been married for an average of 16.9 years, where the average age of the wives was 40.4 years, and of the husbands 41.9 years. Wives with lower satisfaction were more likely to have received a higher education $(63.3 \%)$ than a secondary education $(36.7 \%)$, while the reverse was true for husbands. Husbands with lower satisfaction were more likely to have received a secondary education (56.7\%) than a higher education $(43.3 \%)$.

The SPSS 24.0 PL for Windows computer program was used to calculate the value of the Student's t-test for comparable groups of spouses with higher and lower marital satisfaction levels. ${ }^{26}$

\section{Results}

According to our study results, wives with a higher level of marital satisfaction do not differ significantly from wives with lower marital satisfaction in terms of the social competences that determine the effectiveness of social exposure and require assertive behavior, and also in terms of overall outcomes. However, wives with a higher level of marital satisfaction are more competent in intimate situations - $t$ (58) $=2.13 ; \mathrm{p}<0.04$, than wives with less marital satisfaction (see Table 1).

Table 1. The social competence of wives who experience greater and lesser marital satisfaction

\begin{tabular}{|l|c|c|c|c|c|c|}
\hline \multirow{2}{*}{ Social Competence } & \multicolumn{2}{|c|}{$\begin{array}{c}\text { Wife with } \\
\text { Higher } \\
\text { Satisfaction } \\
(\mathbf{n = 3 0 )}\end{array}$} & \multicolumn{2}{c|}{$\begin{array}{c}\text { Wife with } \\
\text { Lower } \\
\text { Satisfaction } \\
(\mathbf{n = 3 0 )}\end{array}$} & \multicolumn{2}{|c|}{ Difference } \\
\cline { 2 - 7 } & Mean & SD & Mean & SD & t & p< \\
\hline Intimacy & 46.43 & 7.62 & 42.87 & 5.07 & 2.13 & 0.04 \\
\hline Social Exposure & 50.50 & 7.52 & 50.80 & 8.86 & -0.14 & n.s. \\
\hline Assertiveness & 47.6 & 7.26 & 45.10 & 7.33 & 1.33 & n.s. \\
\hline Total Score & 176.03 & 19.07 & 171.03 & 19.55 & 1.0 & n.s. \\
\hline
\end{tabular}

Note: "n.s." means "not statistically significant"

Husbands with higher and lower levels of marital satisfaction demonstrated similar results as wives in terms of their competencies that

$26 \quad$ S. Bedyńska and M. Cypryańska, "Testy t-Studenta i ich nieparametryczne odpowiedniki," Statystyczny drogowskaz 1. Praktyczne wprowadzenie do wnioskowania statystycznego, ed. S. Bedyńska and M. Cypryańska (Warsaw: 2013): 180-184. 
determine the effectiveness of behavior in situations that require social exposure. On the other hand, husbands with a higher level of marital satisfaction achieved significantly higher results in terms of their behavior in intimate situations - $\mathrm{t}(58)=3.79$; $\mathrm{p}<0.01$, their assertiveness $-\mathrm{t}(58)=2.85 ; \mathrm{p}<0.01$, and their total score $-\mathrm{t}(58)=3.09$; $\mathrm{p}<0.01$ (see Table 2).

Table 2. The social competence of husbands who experience greater and lesser marital satisfaction

\begin{tabular}{|l|c|c|c|c|c|c|}
\hline \multirow{2}{*}{ Social Competence } & \multicolumn{2}{|c|}{$\begin{array}{c}\text { Husband } \\
\text { with Higher } \\
\text { Satisfaction } \\
(\mathbf{n = 3 0 )}\end{array}$} & \multicolumn{2}{c|}{$\begin{array}{c}\text { Husband } \\
\text { with Lower } \\
\text { Satisfaction } \\
\text { (n=30) }\end{array}$} & \multicolumn{2}{|c|}{ Difference } \\
\cline { 2 - 7 } & Mean & SD & Mean & SD & t & p< \\
\hline Intimacy & 43.3 & 6.51 & 37.03 & 6.30 & 3.79 & 0.01 \\
\hline Social Exposure & 52.5 & 8.70 & 49.53 & 8.32 & 1.35 & n.s. \\
\hline Assertiveness & 51 & 7.03 & 45.90 & 6.83 & 2.85 & 0.01 \\
\hline Total Score & 179.77 & 22.95 & 162.63 & 19.95 & 3.09 & 0.01 \\
\hline
\end{tabular}

Note: "n.s" means "not statistically significant"

\section{Discussion}

Of the three types of social competency: intimacy, social exposure, and assertiveness, spouses who demonstrated higher social competency in intimate situations also demonstrated a higher level of marital satisfaction. This makes sense due to the fact that effective marital intimacy enables a dialogue, ${ }^{27}$ through which the spouses can open themselves up ${ }^{28}$ and come to know each other better. ${ }^{29}$ Social competency in the form of intimacy can potentially lead to effective interpersonal communication free of: 1) distracted attention that is fixed on only one channel

27 J. Baniak, “Znaczenie dialogu w małżeństwie,” Małżeństwo i Rodzina 1, no. 9 (2004): 25-28.

28 M. McKay, M. Davis, and P. Fanning, Messages: The Communication Skills Book. E-Book: Kindle (Oakland: New Harbinger Publications, 2009), 34-41.

$29 \quad$ M.Piasecka, "Wiedza o sobie i wiedza o partnerze a ocena jakości małżeństwa," Psychologia w stużbie rodziny, eds. I. Janicka and T. Rostowska (Lodz: Fundacja Fides et Ratio 2003): 78-88; A. Dakowicz, "Wiedza o sobie nawzajem małżonków charakteryzujących się wysokim i niskim poziomem transgresji," Przegląd Psychologiczny 58, no. 1 (Lublin: 2015a): 39. 
of communication-verbal or nonverbal; 2) the wrong form of expression, which occurs when spouse imposes a certain way of relating that opposes the other spouse; 3 ) parallel communication, which occurs when the spouses do not mutually interact with or respond to each other; 4) paradoxical communication, which occurs when a spouse's nonverbal and verbal forms of communication conflict with each other, thereby conveying two opposite messages. ${ }^{30}$ Most likely, a high level of social competence that determines the effectiveness of intimate behavior helps promote deeper insight in the spouses in their relationship. In this way, they are able to realize who and what contributes to the relationship, who benefits from this, and whether it suits them. Reflecting on a marital relationship in this way makes it possible to correct the situation and, thereby, avoid a situation where, even if the relationship lasts, one spouse is dependent on the other. For, an unequal relationship where the burden falls more on one spouse or the other leads to greater marital dissatisfaction. When one spouse gives more than the other, this can lead: 1) the spouse who "gives more" to feel used by the other spouse, and 2) the spouse who "gives less" to remorse and weariness with the other spouse. ${ }^{31}$

According to Robert H. Sternberg, in addition to passion and engagement, intimacy is a key ingredient of love. Intimacy is expressed in mutual understanding, sharing experiences, exchanging intimate information, and giving and receiving emotional support. ${ }^{32}$ Gary Chapman, who writes about the five love languages (words of affirmation, quality time, receiving gifts, acts of service, and physical touch), emphasizes that spouses have a good marital relationship when they know the love language that the other spouse uses every day to express mutual love. This awareness is also undoubtedly related to the intimate sphere of

\footnotetext{
30 A. Tomorowicz, "Struktura kompetencji społecznych w ujęciu interakcyjnym," Psychiatria 8, no. 3 (2011): 95.

31 E. Mandal, Miłość, władza i manipulacja w bliskich zwiazkach (Warsaw: Wydawnictwo Naukowe PWN, 2008), 200.

32 R.J.Sternberg, “A triangular theory of love," Psychological Review 93 (American Psychological Association, 1986): 119-135.
} 
marriage. ${ }^{33}$ Spouses who are competent in the sphere of intimacy try to fulfill not only their own vision for their marital relationship, but also the idea that they are part of a common story to which their spouse must agree and be a part. ${ }^{34}$ Competence in intimacy makes it possible for spouses to respond to emerging issues and new situations in a way that suits them both. ${ }^{35}$ As a result, they can avoid (or at least minimize) negative emotional Anthropology stress triggers that decreases the quality of their relationship. ${ }^{36}$

Husbands with a higher level of marital satisfaction outperformed husbands with lower levels of marital satisfaction with regard to social competence in situations requiring assertiveness. The nature of social competence that determines the effectiveness of behavior in situations requiring assertiveness is similar to the general expectation that of men should rule, fight, educate, and be capable of friendship. ${ }^{37}$ Men's fulfillment of these expectations favors so-called 'psychological androgyny," ${ }^{38}$ which is the result of a shift in understanding the role of men in today's world. ${ }^{39}$ An androgynous man is one who highly exhibits both masculine (instrumental) and feminine (expressive) traits. When having to take action, he is able to firmly refuse something without being aggressive, and when necessary, he can provide psychological support by patiently listening to the intimate confidences of his wife or child. Compared to typical men, androgynous men have

33 G. Chapman, The 5 Love Languages: The Secret to Love that Lasts, E-Book: Kindle (Chicago: Northfield Publishing, 2015), 15.

R. J. Sternberg, Love is a Story, E-Book: Kindle (Oxford: Oxford University Press, 1998), 17.

M. Plopa, "Więzi małżeńskie i rodzinne w perspektywie teorii przywiązania," Psychologia rodziny, eds. I. Janicka and H. Liberska (Warsaw: Wydawnictwo Naukowe PWN, 2014): 158.

A. Dakowicz, Powodzenie matżeństwa, 215.

S. Weber, The Tender Warrior, E-Book: Kindle (Oregon: Multnomah, 2009), 46-51.

A. Dakowicz, Płeć psychiczna a poziom samoaktualizacji (Bialystok: Wydawnictwo Uniwersyteckie Trans Humana 2000), 30.

39 E. Badinter, XY tożsamość mężczyzny (Warsaw: Wydawnictwo WAB, 1993), 160-162. 
a greater sense of security and self-actualization ${ }^{40}$ because of $^{2}$ their flexibility and ability to respond adequately to the situations that arise.

\section{Conclusion}

Spouses who experience more marital satisfaction are more socially competent and therefore able to demonstrate more effective behavior in intimate situations than those spouses who are less satisfied. Their competence enables them to build close marital relationships in the ever-changing reality of life and marriage. By counting on their inner world and the their spouse's feelings, they act in a way that increases the probability of creating a relationship that is satisfying to both spouses, which, in turn, positively influences the family atmosphere. Since social competences improve spousal marital satisfaction, which subsequently creates a positive educational atmosphere in the family, special attention should be paid to the need to acquire and develop these competences, which are acquired in the course of social training and in various social settings. Family is the first environment in which a person becomes socially competent ${ }^{41}$ so it is necessary for parents create conditions that will help their children acquire social competences. ${ }^{42}$ To promote an increase in social competences, educational institutions can run various types of social skills training programs and courses for children, ${ }^{43}$ parents, ${ }^{44}$ and educators. ${ }^{45}$

$40 \quad$ A. Dakowicz, "Specyfika wybranych czynników osobowości kobiet i mężczyzn o różnym typie płci psychologicznej," Edukacja: Teologia i Dialog 11 (2015b): 104.

41 S. Kawula, J. Brągiel, and A.W. Janke, Pedagogika rodziny. Obszary i panorama problematyki (Torun: 2014), 83-84.

42 J. Wilk, Pedagogika rodziny (Lublin: Instytut Pedagogiki Katolickiego Uniwersytetu Lubelskiego 2016), 110-126.

43 D.M. Plummer, Social Skills Games for Children (London: Jessica Kingsley Publishers, 2008).

44 L. Dakowicz and A. Dakowicz, "Wychowanie do życia w rodzinie - wspólna troska białostockiej społeczności lokalnej o przyszłość młodego pokolenia," Studia nad Rodzina 35, no. 2 (2014): 71.

45 L.Dakowicz, A. Dakowicz, "Trening doskonalący kompetencje wychowawcze," Kwartalnik Edukacja 3 (2009a): 127-131; L. Dakowicz, A. Dakowicz, "Trening umiejętności wychowawczych jako forma doskonalenia zawodowego nauczyciela," Pomoc psychologiczno-pedagogiczna w szkole. Wybrane zagadnienia, ed. M. Wróblewska (Bialystok: 2009b): 80-85. 


\section{PSYCHOLOGICZNO-PEDAGOGICZNA ANALIZA KOMPETENCJI SPOŁECZNYCH MAŁŻONKÓW O WYŻSZYM I NIŻSZYM POZIOMIE ZADOWOLENIA ZE SWOJEGO ZWIĄZKU}

Celem opracowania jest poszukiwanie odpowiedzi na pytanie: Czy małżonkowie o wyższym i niższym poziomie zadowolenia ze swojego związku różnią się pod względem posiadanych kompetencji społecznych? Wykorzystując Skalę Powodzenia Małżeństwa M. Braun-Gałkowskiej i Kwestionariusz Kompetencji Społecznych A. Matczak zbadano 75 małżeństw, spośród których wyodrębniono po 30 par o wyższym i niższym poziomie zadowolenia ze swojego związku. Małżonkowie o wyższym poziomie zadowolenia ze swojego związku charakteryzują się większymi kompetencjami warunkującymi efektywność zachowań w sytuacjach intymnych, niż małżonkowie o niższym poziomie zadowolenia ze swojego związku. Podobną prawidłowość zarejestrowano w przypadku badanych mężów, w odniesieniu do kompetencji warunkujących efektywność zachowań w sytuacjach wymagających asertywności. Posiadane przez małżonków kompetencje społeczne wspomagają budowanie bliskiej relacji małżeńskiej pozytywnie wpływającej na klimat życia rodzinnego.

Słowa kluczowe: powodzenie małżeństwa, kompetencje społeczne, sytuacje intymne, ekspozycja społeczna, asertywność, klimat życia rodzinnego.

\section{Bibliography:}

1. Alberti, R. and M. Emmons. Asertywność. Sięgaj po to, czego chcesz, nie raniac innych. Gdansk: Gdanskie Wydawnictwo Psychologiczne, 2007.

2. Argyle, M. The Psychology of Interpersonal Behavior. E-Book: Kindle. United Kingdom: Penguin, 1994.

3. Aronson, E. The Social Animal. New York: Worth Publishers, 2008.

4. Badinter, E. XY tożsamość mężczyzny. Warsaw: Wydawnictwo WAB, 1993.

5. Baniak, J. "Znaczenie dialogu w małżeństwie." Matżeństwo i Rodzina 1, no. 9 (2004), 25-28.

6. Bedyńska, S., and M. Cypryańska. "Testy t-Studenta i ich nieparametryczne odpowiedniki." Statystyczny drogowskaz 1. Praktyczne wprowadzenie do wnioskowania statystycznego. Edited by S. Bedyńska and M. Cypryańska. Warsaw (2013): 180-184.

7. Braun-Gałkowska, M. Miłość aktywna. Psychiczne uwarunkowania powodzenia w matżenstwie. Warsaw: Instytut Wydawniczy PAX, 1985.

8. Braun-Gałkowska, M. Psychologiczna analiza systemów rodzinnych osób zadowolonych i niezadowolonych $z$ matżeństwa. Lublin: Towarzystwo Naukowe KUL, 1992.

9. Braun-Gałkowska, M. Psychologia domowa. Lublin: Wydawnictwo Katolicki Uniwersytet Lubelski, 2008. 
10. Braun-Gałkowska, M. "Psychoprofilaktyka życia rodzinnego.” Psychologia $w$ stuzbie rodziny. Edited by I. Janicka and T. Rostowska. Lodz: Fundacja Fides et Ratio (2003): 11.

11. Chapman, G. The 5 Love Languages: The Secret to Love that Lasts. E-Book: Kindle. Chicago: Northfield Publishing, 2015.

12. Dakowicz, A. Płeć psychiczna a poziom samoaktualizacji. Bialystok: Wydawnictwo Uniwersyteckie Trans Humana 2000.

13. Dakowicz, A. Powodzenie matżenstwa. Uwarunkowania psychologiczne $w$ perspektywie transgresyjnego modelu Józefa Kozieleckiego. Bialystok: Wydawnictwo Uniwersyteckie Trans Humana, 2014.

14. Dakowicz, A. "Postawy rodzicielskie małżonków zadowolonych i niezadowolonych ze swojego związku." W świecie dziecka. Wybrane zagadnienia $z$ psychologii wychowawczej $i$ rodziny. Edited by B. Lachowska and M. Grygielski. Lublin (1999): 73-87.

15. Dakowicz, A. "Wiedza o sobie nawzajem małżonków charakteryzujących się wysokim i niskim poziomem transgresji." Przegląd Psychologiczny 58, no. 1. Lublin (2015a): 39.

16. Dakowicz, A. "Specyfika wybranych czynników osobowości kobiet i mężczyzn o różnym typie płci psychologicznej." Edukacja: Teologia $i$ Dialog 11 (2015b): 104.

17. Dakowicz, L. and A. Dakowicz. "Trening doskonalący kompetencje wychowawcze." Kwartalnik Edukacja 3 (2009a): 127-131.

18. Dakowicz, L., and A. Dakowicz. "Trening umiejętności wychowawczych jako forma doskonalenia zawodowego nauczyciela." Pomoc psychologiczno-pedagogiczna w szkole. Wybrane zagadnienia. Edited by M. Wróblewska. Bialystok (2009b): 80-85.

19. Dakowicz, L., and A. Dakowicz, "Wychowanie do życia w rodzinie wspólna troska białostockiej społeczności lokalnej o przyszłość młodego pokolenia," Studia nad Rodzina 35, no. 2 (2014): 71.

20. Elżanowska, H. "Skala Powodzenia Małżeństwa w badaniach prowadzonych pod kierunkiem Profesor Marii Braun-Gałkowskiej." In Dalej w tę sama strone. Księga Jubileuszowa dedykowana Profesor Marii BraunGatkowskiej. Edited by I. Ulfik-Jaworska and A. Gała. Lublin: Wydawnictwo Katolicki Uniwersytet Lubelski, 2012, 61-87.

21. Harwas-Napierała, B. "Specyfika komunikacji interpersonalnej w rodzinie ujmowanej jako system." Psychologia rodziny. Edited by I. Janicka and H. Liberska. Warsaw (2014): 48.

22. Jankowiak, B., and K. Waszyńska. "Współczesne formy życia partnerskiego. Analiza jakości i trwałości relacji." Nowiny Lekarskie 80, no. 5 (2011): 360-363.

23. Kawula, S., J. Brągiel, and A. W. Janke. Pedagogika rodziny. Obszary i panorama problematyki. Torun (2014), 83-84.

24. Król-Fijewska, M. "Historie małżeńskie." Sztuka relacji międzyludzkich. Miłość, matżeństwo, rodzina. Edited by J. Augustyn. Cracow: Wydawnitcwo WAM (2014): 313-320.

25. Kuryś-Szyncel, K. “Od małżeństwa do rodzicielstwa. Analiza zmian rozwojowych w systemie rodzinnym." Rodzina w ujęciu systemowym. 
Teoria $i$ badania. Edited by A. Margasiński. Warsaw: Pracownia Testów Psychologicznych (2015): 100-118.

26. Lazarus, R. S. "On the Primacy of Cognition." American Psychologist 39, no. 2. Washington, DC: American Psychological Association (1984): 124-129.

27. Leary, M. R., and R. M. Kowalski. "Impression Management: A Literature Review and Two-Component Model." Psychological Bulletin 107, no. 1. American Psychological Association (1990): 34-47.

28. Ładyżyński, A.K. "Razem w niestabilnych czasach." Sztuka relacji międzyludzkich. Mitość, matżeństwo, rodzina. Edited by J. Augustyn. Cracow: Wydawnictwo WAM (2014): 331-337.

29. Mandal, E. Miłość, władza i manipulacja $w$ bliskich zwiazkach. Warsaw: Wydawnictwo Naukowe PWN, 2008.

30. Matczak, A. Kwestionariusz Kompetencji Społecznych. Podręcznik. Warsaw: Pracownia Testow Psychologicznych 2001.

31. McKay, M., M. Davis, and P. Fanning, Messages: The Communication Skills Book (Oakland: New Harbinger Publications, 2009), 34-41.

32. Piasecka, M. "Wiedza o sobie i wiedza o partnerze a ocena jakości małżeństwa." Psychologia w stużbie rodziny. Edited by I. Janicka and T. Rostowska. Lodz: Fundacja Fides et Ratio (2003): 78-88.

33. Plopa, M. "Więzi małżeńskie i rodzinne w perspektywie teorii przywiązania." Psychologia rodziny. Edited by I. Janicka and H. Liberska. Warsaw: Wydawnictwo Naukowe PWN (2014): 158.

34. Plummer, D.M. Social Skills Games for Children. London: Jessica Kingsley Publishers, 2008.

35. Sternberg, R.J. "A triangular theory of love." Psychological Review 93. American Psychological Association (1986): 119-135.

36. Sternberg, R. J. Love is a Story. Oxford: Oxford University Press, 1998.

37. Świętochowski, W. "Rodzina w ujęciu systemowym." Psychologia rodziny. Edited by I. Janicka, H. Liberska. Warsaw (2014): 31-32.

38. Tomorowicz, A. "Struktura kompetencji społecznych w ujęciu interakcyjnym." Psychiatria 8, no. 3 (2011): 95.

39. Walczak, M. "Dylematy życia małżeńskiego. Rzecz o dynamice i kryzysach w relacjach małżeńskich." Psychologia $w$ stużbie rodziny. Edited by Janicka and T. Rostowska. Lodz: Fundacja Fides et Ratio (2003): 102-108.

40. Weber, S. The Tender Warrior. E-Book: Kindle. Oregon: Multnomah, 2009.

41. Wilk, J. Pedagogika rodziny. Lublin: Instytut Pedagogiki Katolickiego Uniwersytetu Lubelskiego, 2016. 